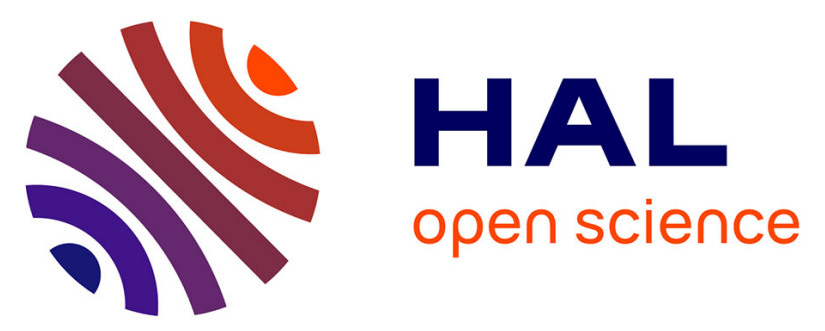

\title{
Exercise training improves functional post-ischemic recovery in senescent heart
}

Christine Le Page, Philippe Noirez, José Courty, Bruno Riou, Bernard Swynghedauw, Sophie Besse

\section{- To cite this version:}

Christine Le Page, Philippe Noirez, José Courty, Bruno Riou, Bernard Swynghedauw, et al.. Exercise training improves functional post-ischemic recovery in senescent heart. Experimental Gerontology, 2009, 44 (3), pp.177. 10.1016/j.exger.2008.10.003 . hal-00493089

\section{HAL Id: hal-00493089 \\ https://hal.science/hal-00493089}

Submitted on 18 Jun 2010

HAL is a multi-disciplinary open access archive for the deposit and dissemination of scientific research documents, whether they are published or not. The documents may come from teaching and research institutions in France or abroad, or from public or private research centers.
L'archive ouverte pluridisciplinaire HAL, est destinée au dépôt et à la diffusion de documents scientifiques de niveau recherche, publiés ou non, émanant des établissements d'enseignement et de recherche français ou étrangers, des laboratoires publics ou privés. 


\section{Accepted Manuscript}

Exercise training improves functional post-ischemic recovery in senescent heart

Christine Le Page, Philippe Noirez, José Courty, Bruno Riou, Bernard

Swynghedauw, Sophie Besse

PII:

S0531-5565(08)00325-2

DOI:

10.1016/j.exger.2008.10.003

Reference:

EXG 8559

To appear in:

Experimental Gerontology

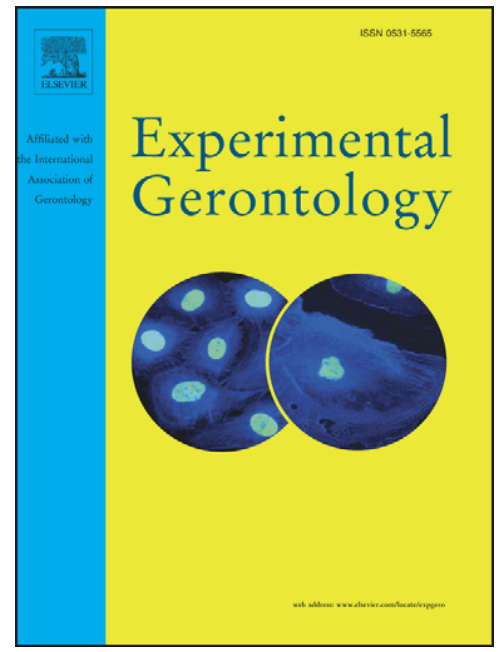

Received Date: $\quad 5$ June 2008

Revised Date: $\quad 16$ September 2008

Accepted Date: $\quad 9$ October 2008

Please cite this article as: Page, C.L., Noirez, P., Courty, J., Riou, B., Swynghedauw, B., Besse, S., Exercise training improves functional post-ischemic recovery in senescent heart, Experimental Gerontology (2008), doi: 10.1016/ j.exger.2008.10.003

This is a PDF file of an unedited manuscript that has been accepted for publication. As a service to our customers we are providing this early version of the manuscript. The manuscript will undergo copyediting, typesetting, and review of the resulting proof before it is published in its final form. Please note that during the production process errors may be discovered which could affect the content, and all legal disclaimers that apply to the journal pertain. 


\section{Exercise training improves functional post-ischemic recovery in senescent heart}

Christine Le Page $1,2,{ }^{*}$, Philippe Noirez 2,3 , José Courty ${ }^{1}$, Bruno Riou ${ }^{4}$, Bernard Swynghedauw ${ }^{5}$, Sophie Besse 1,2 .

1 Laboratoire Croissance cellulaire, Réparation et Régénération Tissulaires, UMR CNRS 7149, Université Paris Est, Créteil.

2 Université Paris Descartes, Paris, France.

3 INSERM U787, Institut de Myologie, Université Pierre et Marie Curie-Paris 6, Paris, France

4 Laboratoire d'Anesthésiologie, EA 3975, Université Pierre et Marie Curie-Paris 6 and Service d'Accueil des Urgences, CHU Pitié-Salpêtrière, Assistance PubliqueHôpitaux de Paris, France.

5 INSERM U572, Paris, France

Corresponding author : Christine Le Page

Laboratoire Croissance cellulaire, Réparation et Régénération Tissulaires, UMR CNRS 7149

Faculté des Sciences et Techniques, Université Paris Est

61 Avenue du Général de Gaulle

94010 Créteil cedex, France

Tel : 33145171815

Fax : 33145171816

e-mail: Christine.Le-Page@univ-paris5.fr

Running title: Exercise and cardioprotection in aging

Keywords: Exercise; Aging; Cardioprotection; Ischemic cardiac diseases; Oxidative stress, Heat-shock-protein 70; Endothelial nitric oxide synthase 


\section{ABSTRACT}

The incidence of ischemic cardiac diseases increases with age and elderly subjects are more vulnerable to myocardial infarction. Endurance exercise (e.g. treadmill training) provides cardioprotection against an ischemia and reperfusion (IR) event in adult heart but such a potential beneficial effect of regular exercise has never been evaluated during aging. Therefore, this study investigated the effects of moderate running training on post-ischemic recovery of contractile function and coronary perfusion in senescent myocardium. Isolated hearts of sedentary (24 mo-sedentary; $n=10$ ) and trained senescent (24 mo-trained; $n=11$; moderate running: $1 \mathrm{~h} /$ day, 5 days/week for 12 weeks) rats were submitted to 45 min low-flow ischemia (15\% of initial coronary flow (CF)) followed by 30 min reperfusion. Active tension (AT) and CF were recorded at baseline and after 1, 3, 5, 10, 15, 20, 25, 30 min of reperfusion. Left ventricular protein carbonylation, and both heat-shock-protein 70 (HSP70) and endothelial nitric oxide synthase (eNOS) contents were determined by Oxyblotting and Western blotting, respectively. Regular physical exercise improves impairment of functional post-ischemic recovery (AT and CF) of aged hearts during reperfusion and this cardioprotection is associated to limited protein oxidation and increased HSP70 and eNOS myocardial contents.

Keywords: Exercise; Aging; Cardioprotection; Ischemic cardiac diseases; oxidative stress; Heat Shock Protein 70, endothelial nitric oxide synthase 


\section{Introduction}

The population of patients with coronary artery disease is growing and ischemic cardiac diseases are the leading cause of morbidity and mortality in the industrialized countries. The primary pathological expression of ischemic cardiac diseases is myocardial injury due to an ischemia-reperfusion (IR) insult and the majority of ischemic events occur in individuals over the age of 65 years. Despite improvements in myocardial operative technique, age remains a major risk factor for mortality and postoperative morbidity for all forms of cardiac surgery (Ivanov et al., 1998). This age associated difference have, at least partly, a myocardial basis because aged heart manifest poor functional recovery after an IR compared with younger counterparts in animal models (Assayag et al., 1998; Besse et al., 2001, 2004, 2006). Consequently, the development of cardioprotective strategies for senescent myocardium constitutes an important aim for public health.

Epidemiological data clearly show that regular physical exercise exerts a protective effect against the morbidity and mortality associated with ischemic cardiac disease (reviewed in Ferrara et al., 2002; Roberts and Barnard, 2005; Kruk, 2007). Physical activity reduces the risk and attenuates progression of ischemic heart disease (Niebauer et al., 1997; Shephard and Balady, 1999; Sundquist et al., 2005). Experimental studies using trained rat models (e.g treadmill running) have demonstrated that these epidemiological observations can be, at least partly, attributed to an exercise-induced cardioprotection against a variety of cellular mechanisms involved in deleterious effects of ischemia and reperfusion (Brown and 
Moore, 2007; Powers et al., 2008). However, these studies were carried out on young adult rats ( $<6$ month of age) whereas most cardiac complications occur in late adulthood. Aging process is responsible for structural and functional changes in heart (reviewed in Marin, 1995; Lakatta and Sollott, 2002) that decrease its capacity to tolerate and respond to various stress, especially IR. Indeed, aging is associated with exaggerated oxidative injury (Boucher et al., 1998; Liu et al., 2004; Besse et al., 2006), decreased endogenous protective mechanisms to stress (Verbeke et al., 2001) and impairment of coronary perfusion resulting, at least partly, from decreased nitric oxide (NO) bioavailablility (Haendeler, 2006). In aged rats, only two studies have investigated the protective effect of running exercise on post-ischemic recovery of heart function and both used a short-term exercise i.e. one (Starnes et al., 2003) and three (Quindry et al., 2005) sessions. As patients can rarely anticipate an ischemic episode, acute exercise is difficult to plan even it is able to protect against an ischemic injury and consequently, such cardioprotection have poor clinical relevance. The potential sustainable beneficial effect of exercise have never been investigated on recovery of cardiac function after ischemia-reperfusion in aged hearts. Consequently, the aim of this study was to determine whether a regular exercise is able to induce sustainable cardioprotection against IR event in senescent rat hearts. To clarify the involved mechanisms, we also investigated the three major pathways (oxidative stress, HSP70 and endothelial function/coronary circulation) involved in both the particular vulnerability of the senescent heart to IR (Besse et al., 2006; Taylor and Starnes, 2003) and in endurance training-induced protection after

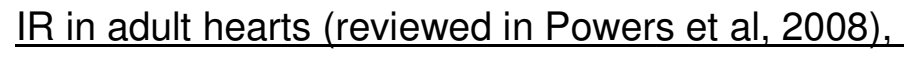




\section{Methods}

\subsection{Animals groups and training protocol}

Senescent (24 month old (mo)) male Wistar rats were obtained from Charles River Laboratories (Saint Germain sur L'arbresle, France). All protocols used in this study were in agreement with the Guidelines for the Care and Use of Laboratory Animals published by the US National Institutes of Health (NIH Publication No 85-23, revised 1996) and the study was performed under the supervision of authorized researchers in authorized laboratories. All animals were housed in the same facility with a 12:12-h light-dark cycle, with food and water provided ad libitum. The following groups were used: sedentary senescent (24 mo-sedentary; $n=10$ ) and trained senescent (24 mo-trained; $n=11$ ) rats. The endurance exercise program consisted of treadmill rapidly walking for 12 weeks, after one week acclimatization to the motordriven treadmill (this included daily handling and walking on the treadmill), as previously described (Tate et al., 1996). The two first weeks, rats ran 5-10 min at 10$16 \mathrm{~m} / \mathrm{min}$ at a $5 \%$ grade, 5 days/week. Exercise duration was gradually increased to $60 \mathrm{~min} /$ day, over 4 weeks, so that the rats exercised continuously $15 \mathrm{~min} /$ day the third week, $30 \mathrm{~min} /$ day the fourth week, $45 \mathrm{~min} /$ day the fifth week and $60 \mathrm{~min} /$ day the sixth week. The duration of $60 \mathrm{~min} /$ day was maintained for the remainder of the program (6 weeks).

All animals were anesthetized $48 \mathrm{~h}$ after the last exercise session of trained rats by i.p. injection of thiopental sodium at $30 \mathrm{mg} / \mathrm{kg}$ (Nesdonal, Specia, RhônePoulenc Rorer, Paris, France). A supplementary sedentary 24 mo rat was sacrificed to obtain control left ventricle protein sample used for Oxyblotting and Western blot analysis. To verify the efficiency of the training program, the soleus muscle was 
excised from all rats, immediately frozen in liquid nitrogen, and stored at $-80^{\circ} \mathrm{C}$ until processed for the measurement of citrate synthase activity.

\subsection{Citrate synthase activity measurement in soleus muscle}

Activity of citrate synthase, a good marker of oxidative metabolism, was measured in soleus muscle (Srere, 1969). Briefly, after muscle homogenization in potassium phosphate buffer, the absorbance of the reaction (mixture solution: $1 \mathrm{mM}$ dithio-bis-2-nitro-benzoate (DNTB), $10 \mathrm{mM}$ oxaloacetate, $10 \mathrm{mM}$ acetyl-Coenzyme A and muscle homogenate) was recorded during 3 min by spectrophotometry at 412 $\mathrm{nm}$. Citrate synthase activity was expressed in $\mu \mathrm{mol} \cdot \mathrm{min}^{-1} \cdot \mathrm{g}^{-1}$ of tissue.

\subsection{Isolated perfused heart and ischemia-reperfusion protocol}

After heart excision, Langendorff perfusion under a constant hydrostatic pressure of $75 \mathrm{~mm} \mathrm{Hg}$ was initiated as previously described (Assayag et al., 1998). In all experiments, hearts were perfused with a Krebs-Henseleit bicarbonate buffer (composition in mM: $\mathrm{NaCl} 118, \mathrm{NaHCO}_{3} 25, \mathrm{KCl} 4.8, \mathrm{KH}_{2} \mathrm{PO}_{4} 1.2, \mathrm{MgCl}_{2} 1.2, \mathrm{CaCl}_{2}$ 1.2 , glucose 11 ) at $37^{\circ} \mathrm{C}$, which was continuously bubbled with $95 \% \mathrm{O}_{2}$ and $5 \% \mathrm{CO}_{2}$ to maintain $\mathrm{pH}$ at 7.4. After removal of the right atrium, hearts were paced at 240 beats per minute at $200 \%$ threshold and 2 ms stimulation duration (SD9 stimulator, Grass instrument, Quincy, MA), to prevent arrhythmias during control reperfusion. After 10 min equilibration, baseline values of coronary flow and active tension were measured. Active tension was assessed with a hook attached to a force transducer (type 351, Hugo Sachs Electronik, March-Hugstetten, Germany) connected to a Gould recorder (2000 model, Gould Electronic, Cleveland,Ohio), as previously reported (Assayag et al., 1998). The system was then switched to flow-controlled 
perfusion for $10 \mathrm{~min}$, each heart being constantly perfused at its own initial coronary flow with a peristaltic pump (Minipulse 3, Gilson, Villiers le bel, France). The hearts were submitted to 45 min low-flow ischemia by reducing the coronary flow to $15 \%$ of its initial value. During ischemia, pacing was stopped and an acrylic cover was placed over the perfusion chamber to maintain the temperature at $37^{\circ} \mathrm{C}$. After $45 \mathrm{~min}$ ischemia, the hearts were reperfused according to Langendorff under a constant hydrostatic pressure of $75 \mathrm{~mm} \mathrm{Hg}$. Coronary flow and active tension were measured after $1,3,5,10,15,20,25$ and 30 min reperfusion. At the end of perfusion, the hearts were immediately dismounted, weighed quickly and frozen in liquid nitrogen for tissue analysis.

\subsection{Oxyblotting and Western blot analysis}

Protein extraction was performed from individual left ventricles $\underline{(n=10 \text { from } 24}$ mo-sedentary and $\mathrm{n}=11$ from 24 mo-trained rats) as previously reported (Bulteau et al., 2001). Protein oxidation was quantitated with $4 \mu \mathrm{g}$ protein extract by Oxyblotting and quantification of HSP and eNOS proteins was performed with $40 \mu \mathrm{g}$ protein extract by Western blotting. A control protein sample extracted from the control senescent left ventricle was added in all blots.

For detection of protein oxidation, proteins were derivatized to 2,4dinitrophenylhydrazone (DNP-hydrazone) using Oxyblot Protein Oxidation Detection Kit (Intergen company, New-York, USA), by reaction with 2,4 dinitrophenylhydrazine (DNPH). The DNP-derivatized protein samples were separated by electrophoresis in a $12 \%$ polyacrylamide gel and transferred to a nylon membrane (Hybond ECL, Amersham-Phamacia Biotech, Les Ulis, France) for $3 \mathrm{~h}$ at $40 \mathrm{~mA}$. The membranes were incubated with a rabbit polyclonal antibody specific for the DNP moity of the 
proteins (1/5000) in PBS-tween (150 mM NaCl; $10 \mathrm{mM} \mathrm{Na}_{2} \mathrm{HPO}_{4} ; \mathrm{H}_{2} \mathrm{O} ; 0.05 \%$ Tween 20) with 1\% BSA during $1 \mathrm{~h}$ at room temperature (Bulteau et al., 2001). After washes in PBS-tween 0.05\%, membranes were incubated with a goat horseradish peroxidase conjugated antirabbit $\lg$ (1/10000), directed against the primary antibody in PBS-tween $0.05 \%$ with $1 \%$ BSA during $1 \mathrm{~h}$ at room temperature (Bulteau et al., 2001).

For HSP70 and eNOS myocardial expression analyses, proteins were separated on $7.5 \%$ (eNOS) or $12 \%$ (HSP70) SDS-PAGE under reducing conditions and electrophoretically blotted onto polyvinylidenefluoride membranes (Immobilon P, Millipore,Saint-Quentin en Yvelines, France). Membranes were blocked with 5\% non fat dry milk in PBS-Tween $0.1 \%$ overnight at $4^{\circ} \mathrm{C}$ and subsequently incubated at room temperature for 60 min with the mouse monoclonal antibodies specific for either eNOS (1/2000; Transduction Labs, Lexington, KY, USA) or inducible HSP70 (HSP72)(1/1000; SPA 810, Stressgen Biotechnologies, Victoria, BC, Canada). Following incubation, membranes were washed in PBS-Tween $0.1 \%$ and incubated with horseradish peroxidase-conjugated goat anti-mouse lgG (1/50000; Jackson ImmunoResearch laboratories, West Grove, PA).

After incubation with a chemoluminescent reagent (Western Lightening chemiluminescence reagent, Perkin Elmer-Life Sciences, Boston, USA), both Oxyblotting and Western blotting membranes were exposed to ECL films (hyperfilm ECL, Amersham-Phamacia Biotech, Les Ulis, France). The level of protein oxidation and HSP70 and eNOS proteins were determined by scanning densitometry (NIH Image software 1.60). To allow comparison between blots, densitometric score of each sample ( $\mathrm{n}=10$ for 24 mo-sedentary and $\mathrm{n}=11$ for 24 mo-trained groups) was normalized to the densitometric score of the same control protein sample obtained 
from a control senescent left ventricle, added in all blots. To ensure equal protein loading, the membranes were stained by Coomassie blue R-250 immediately after antibody detection.

\subsection{Expression of results and statistical analysis}

Data are expressed as means \pm S.E.M. Coronary flow and active tension of isolated hearts were divided by the weight of wet heart in order to obtain, respectively, CF (milliliters per gram of heart) and AT (gram per gram of heart weight). Statistical analysis was performed using one-way analysis of variance (ANOVA). Differences were considered statistically significant when $\mathrm{P}<0.05$.

\section{Results}

Body weight and heart weight are significantly reduced in 24 mo-trained as compared to 24 mo-sedentary rats (Table 1). However, heart weight-to-body weight ratio is not different between the two groups. This endurance exercise program, which consisted of rapidly walking, is moderate and does not induce cardiac hypertrophy, as previously reported (Tate et al., 1996).

Citrate synthase activity is significantly increased soleus muscle from in 24 mo-trained rats compared to 24 mo-sedentary rats, indicating that the training program was effective in producing adaptation of active skeletal muscle oxidative metabolism (Table 1).

Baseline values of cardiac function (active tension and coronary flow) are not significantly different in 24 mo-trained and 24 mo-sedentary groups (Table 1). However, endurance exercise improves the post-ischemic recovery of contractile function (Fig. 1A) during reperfusion in senescent rats. Moreover, the impairment of 
coronary flow is fully prevented during reperfusion (Fig. 1B). Indeed, at the beginning of reperfusion, the coronary flow rises to $143 \%$ of its baseline value, indicating that vasodilative mechanisms involved in hyperhemia are preserved in trained hearts, as compared to the sedentary hearts. The trained myocardium is better perfused than the sedentary one during all the reperfusion and at the end of reperfusion, the CF reached $7.9 \pm 0.3 \mathrm{~mL} . \mathrm{g}^{-1}$ of heart ( vs $4.5 \pm 0.8 \mathrm{~mL} . \mathrm{g}^{-1}$ of heart; $P<0.001$ ).

As illustrated in Fig. 2, left ventricular protein carbonylation is significantly decreased in 24 mo-trained as compared with 24 mo-sedentary hearts, indicating that endurance training is able to reduce oxidative stress after IR. Moreover, content of HSP70 (Fig. 3) and eNOS (Fig. 4) proteins are strongly increased in 24 mo-trained post-ischemic hearts as compared to 24 mo-sedentary post-ischemic hearts.

\section{Discussion}

We have previously shown that the functional post-ischemic recovery of aged heart is lesser compared with younger counterparts (Besse et al., 2001, 2004, 2006). Thus, the purpose of this study was to examine a potential practical and sustainable countermeasure capable of promoting cardioprotection for senescent myocardium. Our results clearly indicate, for the first time, that moderate running exercise for several weeks protects the aged hearts against an episode of ischemia and reperfusion. This observation is clinically significant because the incidence and severity of ischemic events is greatest in older persons. This protective effect of physical exercise, characterized by an improvement in post-ischemic recovery of contractile function and coronary flow, is associated to limited protein oxidation and increased HSP70 and eNOS myocardial contents. 
The aged heart is characterized by an increased reactive oxygen species (ROS) production (Maurel et al., 2003; Oudot et al., 2006) and reduced antioxidant defenses (Sivonova et al., 2006) which are implicated in particular vulnerability of heart to ischemia and reperfusion during aging (Boucher et al., 1998; Liu et al., 2004; Besse et al., 2006). We show here that regular physical exercise strongly decreases protein carbonylation, the most widely studied modification induced by ROS, in senescent hearts after IR. Such a limitation in cellular oxidative damage could be due to an increase in antioxidant status (Starnes et al., 2003; Quindry et al., 2005; Rinaldi et al., 2006) and/or a reduced production of ROS (Judge et al., 2005). These results suggest that an augmented resistance to oxidative stress by training would participate to the improvement in post-ischemic recovery regarding, respectively, contractile function by decreasing protein oxidation and coronary flow by attenuating the premature breakdown of $\mathrm{NO}$ by ROS and/or limiting oxidative damage in coronary endothelial and smooth muscle cells (Linke et al., 2006). Additional experiments are required to identify specific proteins oxidized after IR in aged heart.

Aging is also associated with a decrease in the ability of cells to cope with environmental challenges and the heat shock response is one of the primordial intracellular defense mechanisms against stressful conditions (Taylor and Starnes, 2003; Verbeke et al., 2001). We found that chronic exercise induces an increased cardiac HSP70 content after IR during aging. Different protective functions have been attributed to HSPs, including repair of ion channels, improvement in ischemiaimpaired $\mathrm{Ca} 2+$ homeostasis, restoration of redox balance, interaction with NOinduced protection, inhibition of proinflammatory cytokines or prevention of proapoptotic pathway activation and HSP70 is the predominant isoform involved in conferring cardioprotection (Chi and Karliner, 2004; Liu et al., 2006a). Given the 
previously reported time period needed for the translation of the HSP70 transcript, our results suggest that regular exercise itself could lead to an elevation in constitutive levels of HSP70 within the myocardium (Melling et al., 2007). Moreover, it has been previously demonstrated that endurance training increases the protein expression of HSP70 in control aged hearts (Rinaldi et al., 2006). Thus, increased HSP70 content in aged trained hearts could participate to an augmented intrinsic resistance to ischemia-reperfusion.

An another aging-induced alteration is an impaired coronary vasoreactivity (decrease in endothelium-dependent vasodilatation and exaggerated coronary vasoconstriction) leading to an impairment of coronary perfusion (Marin, 1995;

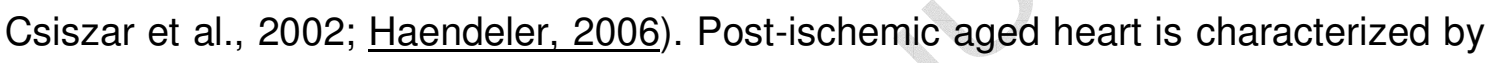
an alteration of coronary flow that is implicated in the particular vulnerability to IR during aging (Besse et al., 2001, 2006). We show in the present study, for the first time, that endurance training preserves the recovery of coronary flow in the senescent heart, as soon as the first minutes of reperfusion, indicating that moderate endurance training is able to preserve the reactive hyperaemia. This protective effect on coronary microvasculature might also account for the preservation of contractile function. Endurance training doubles eNOS myocardial content, as compared to sedentary rats, and this increase in eNOS could participate to the preservation of endothelial function in senescent hearts. Such an increase in eNOS heart content might result from an elevation in constitutive levels of eNOS within the myocardium by regular exercise, because an up-regulation of eNOS expression has been reported in control aged trained hearts (lemitsu et al., 2006). This result has particular relevance because endothelium dysfunction appears to be an important early and integral manifestation of coronary artery disease and is responsible, at 
least in part, for many of the cardiovascular complications associated with aging (Valgimigli et al., 2003). However, the beneficial effects of endurance training on coronary flow could also result from a decrease in responsiveness to vasoconstrictive stimuli such as endothelin (Besse et al., 2001; Symons et al., 2000) and/or a coronary vascular remodeling such as angiogenesis (Brown, 2003; Linke et al., 2006; $\underline{\text { lemitsu et al., 2006; Marini et al., 2008; Leosco et al., 2008). Moreover, increased }}$ eNOS myocardial content by endurance training could also improves the postischemic contractile function by cardiomyocyte-specific mechanisms (Jugdutt, 2002; Razavi et al., 2005 ; Elrod et al., 2006).

In conclusion, the present study demonstrates that regular exercise improves myocardial contractile function and fully prevents the impairment of coronary perfusion after an episode of IR in senescent rats. This experimental result shows, for the first time, that moderate exercise can be a sustainable countermeasure capable of promoting cardioprotection in older age. The potential clinical utility of endurance exercise to mitigate the effects of IR is self-evident and of importance because the development of strategies to reduce the impact of ischemic heart disease in aged population is an increasingly important issue of public health. However, further experimental studies will be needed to improve our understanding of this cardioprotective effect. Indeed, additional investigations are clearly required to $\underline{\text { make an inventory of the multiples mechanisms whereby endurance training can first }}$ protect aging of the heart and second limit its vulnerability to IR and especially: ionichomeostasis (Tani et al., 1999; Besse et al., 2004; Liu et al., 2006b), endothelin production (Besse et al., 2001), Bax/Bcl-2 ratio and apoptosis (Liu et al., 2002) or mitochondrial defects (Lesnefsky et al., 2006). 


\section{Acknowledgements}

This study was supported by grants from Fondation de France and Association Française contre les Myopathies. We thank Angelica Keller for helpful discussion. 


\section{References}

Assayag, P., Charlemagne, D., Marty, I., de Leiris, J., Lompre, A.M., Boucher, F., Valere, P.E., Lortet .S., Swynghedauw , B., Besse, S., 1998. Effects of sustained low-flow ischemia on myocardial function and calcium-regulating proteins in adult and senescent rat hearts. Cardiovasc. Res. 38, 169-180.

Besse, S., Tanguy, S., Riou, B., Boucher, F., Bulteau, A.L., Le Page, C., Swynghedauw, B., de Leiris, J., 2001. Coronary and aortic vasoreactivity protection with endothelin receptor antagonist, bosentan, after ischemia and hypoxia in aged rats. Eur. J. Pharmacol. 432, 167-175.

Besse, S., Tanguy, S., Boucher, F., Le Page, C., Rozenberg, S., Riou, B., de Leiris, J., Swynghedauw B., 2004. Cardioprotection with cariporide, a sodium-proton exchanger inhibitor, after prolonged ischemia and reperfusion in senescent rats. Exp. Gerontol. 39(9), 1307-1314.

Besse, S., Bulteau, A.L., Boucher, F., Riou, B., Swynghedauw, B., de Leiris, J., 2006. Antioxidant treatment prevents cardiac protein oxidation after ischemia-reperfusion and improves myocardial function and coronary perfusion in senescent hearts. J. Physiol. Pharmacol. 57, 541-552.

Boucher, F., Tanguy, S., Besse, S., Tresallet, N., Favier, A., de Leiris, J., 1998. Agedependent changes in myocardial susceptibility to zero flow ischemia and reperfusion in isolated perfused rat hearts: relation to antioxidant status. Mech. Ageing Dev. 103, 301-316. 
Brown, D.A., Moore, R.L., 2007. Perspectives in innate and acquired cardioprotection: cardioprotection acquired through exercise. J. Appl. Physiol. 103, 1894-1899.

Brown, M.D., 2003. Exercise and coronary vascular remodelling in the healthy heart. Exp. Physiol. 88, 645-658.

Bulteau, A.L., Verbeke, P., Petropoulos, I., Chaffotte, A., Friguet, B., 2001. Proteasome inhibition in glyoxal-treated fibroblasts and resistance of glycated glucose-6-phosphate dehydrogenase to $20 \mathrm{~S}$ proteasome degradation in vitro. J. Biol. Chem. 276, 45662-45668.

Chi, N.C., Karliner, J.S., 2004. Molecular determinants of responses to myocardial ischemia/reperfusion injury: focus on hypoxia-inducible and heat shock factors. Cardiovasc. Res. 61, 437-447.

Csiszar, A., Ungvari, Z., Edwards, J.G., Kaminski. P., Wolin, M.S., Koller, A., Kaley, G., 2002. Aging-induced phenotypic changes and oxidative stress impair coronary arteriolar function. Circ. Res. 90, 1159-1166.

Elrod, J.W., Greer, J.J., Bryan, N.S., Langston, Wi., Szot, J.F., Gebregzlabher, H., Janssens, S., Feelisch, M., Lefer, D.J., 2006. Cardiomyocyte-specific overexpression of NO synthase-3 protects against myocardial ischemia-reperfusion injury. Arterioscler Thromb Vasc Biol. 26(7), 1517-1523.

Ferrara, N., Pisanelli, P., Voza, M., Abete, P., Leosco, D., Filippelli, A., Rossi, F., Rengo, F., 2002. The aging heart and exercise training. Arch. Gerontol. Geriatr. Suppl. 8, 145-156. 
Haendeler, J., 2006. Nitric oxide and endothelial cell aging. Eur. J. Clin. Pharmacol. $\underline{62,137-140 .}$

Ivanov, J., Weisel, R.D., David, T.E., Naylor, C.D., 1998. Fifteen-year trends in risk severity and operative mortality in elderly patients undergoing coronary artery bypass graft surgery. Circulation 97, 673-680.

Judge, S., Jang, Y.M., Smith, A., Selman, C., Phillips, T., Speakman, J.R., Hagen, T., Leeuwenburgh, C., 2005. Exercise by lifelong voluntary wheel running reduces subsarcolemmal and interfibrillar mitochondrial hydrogen peroxide production in the heart. Am. J. Physiol. Regul. Integr. Comp. Physiol. 289, R1564-72.

Jugdutt, B.I., 2002. Nitric Oxide and Cardioprotection During Ischemia-Reperfusion. Heart Fail. Rev. 7 (4), 391-405.

Juhaszova, M., Rabuel, C., Zorov, D.B., Lakatta, E.G., Sollott S.J., 2005. Protection in the aged heart: preventing the heart-break of old age? Cardiovasc.Res. 66(2): 233-244.

Kruk, J., 2007. Physical activity in the prevention of the most frequent chronic diseases: an analysis of the recent evidence. Asian Pac. J. Cancer Prev. 8, 325-338.

Kwak, H.B., Song, W., Lawler, J.M., 2006. Exercise training attenuates age-induced elevation in $\mathrm{Bax} / \mathrm{Bcl}-2$ ratio, apoptosis, and remodeling in the rat heart. FASEB J. 20 (6), 791-3.

Lakatta, E.G., Sollott, S.J., 2002. Perspectives on mammalian cardiovascular aging: humans to molecules. Comp. Biochem. Physiol. A. Mol. Integr. Physiol. 132, 699$\underline{721 .}$ 
Lesnefsky, E.J., He, D., Moghaddas, S., Hoppel, C.L., 2006. Reversal of mitochondrial defects before ischemia protects the aged heart. FASEB J. 20 (9), 1543-1545.

Leosco, D., Rengo, G., laccarino, G., Golino, L., Marchese, M., Fortunato, F., Zincarelli, C., Sanzari, E., Ciccarelli, M., Galasso, G., Altobelli, G.G., Conti, V., Matrone, G., Cimini, V., Ferrara, N., Filippelli, A., Koch, W.J., Rengo, F., 2008. Exercise promotes angiogenesis and improves $\{$ beta\}-adrenergic receptor signalling in the post-ischaemic failing rat heart. Cardiovasc. Res. 78, 385-394.

Linke, A., Erbs, S., Hambrecht, R., 2006. Exercise and the coronary circulationalterations and adaptations in coronary artery disease. Prog. Cardiovasc. Dis. 48, 270-284.

Liu, P., Xu,B., Cavalieri,T.A., Hock,C.E., 2002. Age-related difference in myocardial function and inflammation in a rat model of myocardial ischemia-reperfusion. Cardiovasc.Res. 56 (3), 443-453.

Liu, P., Xu, B., Cavalieri, T.A., Hock, C.E., 2004. Attenuation of antioxidative capacity enhances reperfusion injury in aged rat myocardium after MI/R. Am. J. Physiol. Heart Circ. Physiol. 287, H2719-H2727.

Liu, J., Kam , K.W., Borchert, G.H., Kravtsov, G.M., Ballard, H.J., Wong, T.M., 2006a. Further study on the role of HSP70 on $\mathrm{Ca} 2+$ homeostasis in rat ventricular myocytes subjected to simulated ischemia. Am. J. Physiol. Cell Physiol. 290, C583-91.

Liu, J ., Long, C., Ji, B., Zhang, H., Wen, F., 2006b. Myocardial protective effects of nicorandil, an opener of potassium channels on senile rat heart. Perfusion. $21(3), 179-183$. 
Marin, J.,1995. Age-related changes in vascular responses: a review. Mech. Ageing Dev. 79, 71-114.

Marini, M., Falcieri, E., Margonato, V., Trere, D., Lapalombella, R., di Tullio, S., Marchionni, C., Burattini, S., Samaja, M., Esposito, F., Veicsteinas, A., 2008. Partial persistence of exercise-induced myocardial angiogenesis following 4-week detraining in the rat. Histochem. Cell Biol. 129, 479-487.

Maurel, A., Hernandez, C., Kunduzova, O., Bompart, G., Cambon, C., Parini, A., Frances, B., 2003. Age-dependent increase in hydrogen peroxide production by cardiac monoamine oxidase A in rats. Am. J. Physiol. Heart Circ. Physiol. 284, $\mathrm{H} 1460-\mathrm{H} 1467$.

Melling, C.W., Thorp, D.B., Milne, K.J., Krause M.P., Noble, E.G., 2007. Exercisemediated regulation of $\mathrm{Hsp70}$ expression following aerobic exercise training. Am. J. Physiol. Heart Circ. Physiol. 293, H3692-H3698.

Niebauer, J., Hambrecht, R., Velich, T., Hauer, K., Marburger, C., Kalberer, B., Weiss, C., von Hodenberg, E., Schlierf, G., Schuler, G., Zimmermann, R., Kubler, W., 1997. Attenuated progression of coronary artery disease after 6 years of multifactorial risk intervention: role of physical exercise. Circulation 96, 2534-2541.

Oudot, A., Martin, C., Busseuil, D., Vergely, C., Demaison, L., Rochette, L., 2006. NADPH oxidases are in part responsible for increased cardiovascular superoxide production during aging. Free Radic. Biol. Med. 40, 2214-2222.

Powers ,S.K., Quindry, J.C., Kavazis A.N., 2008. Exercise-induced cardioprotection against myocardial ischemia-reperfusion injury. Free Radic. Biol. Med. 44 (2), 193$\underline{201 .}$ 
Quindry, J., French, J., Hamilton, K., Lee, Y., Mehta, J.L., Powers, S., 2005. Exercise training provides cardioprotection against ischemia-reperfusion induced apoptosis in young and old animals. Exp. Gerontol. 40, 416-425.

Razavi, H.M., Hamilton, J.A., Feng, Q., 2005. Modulation of apoptosis by nitric oxide: implications in myocardial ischemia and heart failure. Pharmacol. Ther. 106 (2), 147162.

Rinaldi, B., Corbi, G., Boccuti, S., Filippelli, W., Rengo, G., Leosco, D., Rossi, F., Filippelli, A., Ferrara, N., 2006. Exercice training affects age-induced changes in $\underline{\text { SOD and heat shock protein expression in rat heart. Exp. Geront. } 41 \text { (8), 764-770. }}$

Roberts, C.K., Barnard, R.J., 2005. Effects of exercise and diet on chronic disease. J. Appl. Physiol. 98, 3-30.

Shephard, R.J., Balady, G.J., 1999. Exercise as cardiovascular therapy. Circulation 99, 963-972.

Sivonova. M., Tatarkova, Z., Durackova, Z., Dobrota, Z., Lehotsky, J., Matakova, T., Kaplan, P., 2006. Relationship between antioxidant potential and oxidative damage to lipids, proteins and DNA in aged rats. Physiol. Res. 56 (6), 757-764.

Srere, P.A., 1969. Citrate synthase. Methods Enzymol. 13, 3.

Starnes, J.W., Taylor, R.P., Park, Y., 2003. Exercise improves postischemic function in aging hearts. Am. J. Physiol. Heart Circ. Physiol. 285, H347-H351.

Sundquist, K., Qvist, J., Johansson, S.E., Sundquist, J., 2005. The long-term effect of physical activity on incidence of coronary heart disease: a 12-year follow-up study. Prev. Med. 41, 219-225. 
Symons, J.D., Rendig, S.V., Stebbins, C.L., Longhurst, J.C., 2000. Microvascular and myocardial contractile responses to ischemia: influence of exercise training. J. Appl. Physiol. 88, 433-442.

Tani, M., Honma,Y., Takayama, M., Hasegawa, H., Shinmura, K., Ebihara, Y., Tamaki, K., 1999. Loss of protection by hypoxic preconditioning in aging Fischer 344 rat hearts related to myocardial glycogen content and $\mathrm{Na}+$ imbalance. Cardiovasc. Res. $41(3), 594-602$.

Tate, C.A., Helgason, T., Hyek, M.F., McBride, R.P., Chen, M., Richardson, M.A ., Taffet, G.E., 1996. SERCA2a and mitochondrial cytochrome oxidase expression are increased in hearts of exercise-trained old rats. Am. J. Physiol. 271, H68-72.

Taylor, R.P., Starnes, J.W., 2003. Age, cell signalling and cardioprotection. Acta Physiol. Scand. 178 (2), 107-116.

Valgimigli, M., Merli, E., Malagutti, P., Soukhomovskaia, O., Cicchitelli, G., Macri, G., Ferrari, R., 2003. Endothelial dysfunction in acute and chronic coronary syndromes: evidence for a pathogenetic role of oxidative stress. Arch. Biochem. Biophys. 420, 255-261.

Verbeke, P., Fonager, J., Clark, B.F., Rattan, S.I., 2001. Heat shock response and ageing: mechanisms and applications. Cell. Biol. Int. 25, 845-857.

Yamamura, K., Tani, M., Hasegawa, H., Gen, W., 2001. Very low dose of the $\mathrm{Na}(+) / \mathrm{Ca}(2+)$ exchange inhibitor, KB-R7943, protects ischemic reperfused aged Fischer 344 rat hearts: considerable strain difference in the sensitivity to KB-R7943. Cardiovasc. Res. 52 (3), 397-406. 


\section{Figure legends}

Figure 1. Effects of ischemia-reperfusion on active tension (panel A) and coronary flow (panel B). Mean values \pm S.E.M. for sedentary (24 mo-sedentary, $\mathrm{n}=10$ ) and trained (24 mo-trained, $\mathrm{n}=11)$ senescent hearts. * $\mathrm{P}<0.05$ vs mosedentary group.

Figure 2. Left ventricular protein carbonylation after ischemia-reperfusion. Mean values of densitometric scores \pm S.E.M. for sedentary (24 mo-sedentary, $\underline{n=10}$ ) and trained (24 mo-trained, $\underline{\mathrm{n}=11}$ ) senescent rats. Densitometric scores of each sample were normalized to densitometric score of the same control protein sample obtained from a control senescent left ventricle, present in all blots. ${ }^{*} \mathrm{P}<0.05$ vs mosedentary group.

Figure 3. HSP70 protein content in left ventricle after ischemia-reperfusion. $\underline{\text { Panel A: representative examples of Western blotting analysis. Panel B: mean values }}$ of densitometric scores \pm S.E.M for sedentary ( 24 mo-sedentary, $n=10)$ and trained $\underline{(24 \text { mo-trained, } n=11) \text { senescent rats. Normalization was performed as described in }}$ Fig. 2. * $\mathrm{P}<0.05$ vs mo-sedentary group.

Figure 4. eNOS protein content in left ventricle after ischemia-reperfusion. $\underline{\text { Panel A: representative examples of Western blotting analysis. Panel B: mean values }}$ of densitometric scores \pm S.E.M for sedentary ( 24 mo-sedentary, $n=10)$ and trained (24 mo-trained, $n=11)$ senescent rats. Normalization was performed as described in Fig. 2. * $P<0.05$ vs mo-sedentary group. 
Table 1 : Anatomical and baseline parameters of senescent rat hearts before ischemia and reperfusion

\begin{tabular}{|c|c|c|}
\hline & $\begin{array}{l}24 \text { mo-sedentary } \\
\qquad(\mathrm{n}=10)\end{array}$ & $\begin{array}{c}24 \text { mo-trained } \\
\qquad(\mathrm{n}=11)\end{array}$ \\
\hline Body weight (g) & $477 \pm 3$ & $417 \pm 12$ * \\
\hline Heart weight (g) & $1.55 \pm 0.04$ & $1.45 \pm 0.0$ \\
\hline $\begin{array}{l}\text { Heart weight/body weight } \\
(\mathrm{mg} / \mathrm{g})\end{array}$ & $3.5 \pm 0.30$ & $3.5 \pm 0.12$ \\
\hline $\begin{array}{l}\text { Citrate synthase activity } \\
\text { ( } \mu \mathrm{mol} \cdot \mathrm{min}^{-1} \cdot g^{-1} \text { tissue) }\end{array}$ & $11.6 \pm 0.5$ & $16.2 \pm 0.9$ * \\
\hline $\begin{array}{l}\text { Active tension } \\
\text { (g. } \mathrm{g}^{-1} \text { heart weight) }\end{array}$ & $6.9 \pm 0.3$ & $7.4 \pm 0.5$ \\
\hline $\begin{array}{l}\text { Coronary flow } \\
\text { (mL.g }{ }^{-1} \text { heart weight) }\end{array}$ & $5 \pm 0.5$ & $8.9 \pm 0.4$ \\
\hline
\end{tabular}


A
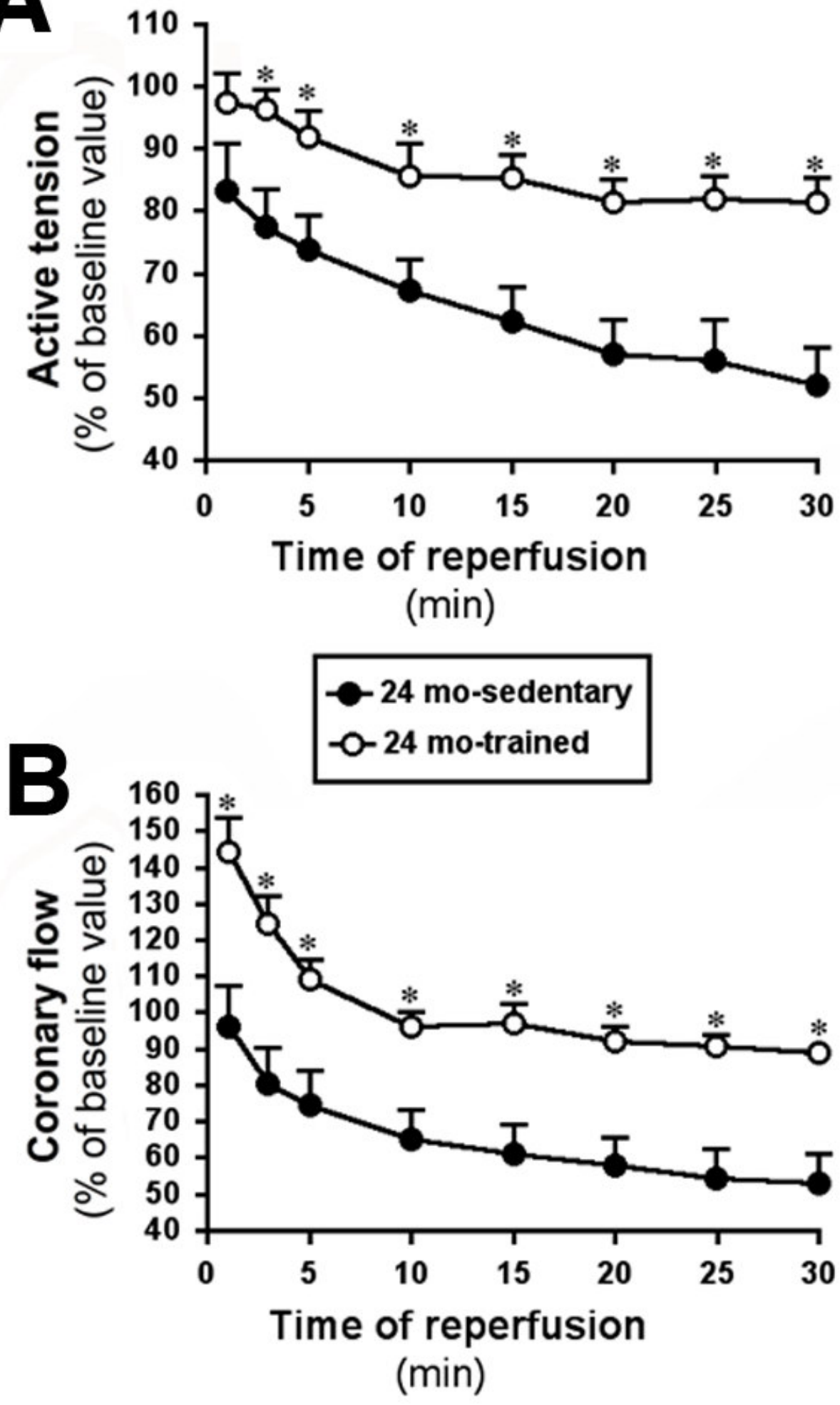


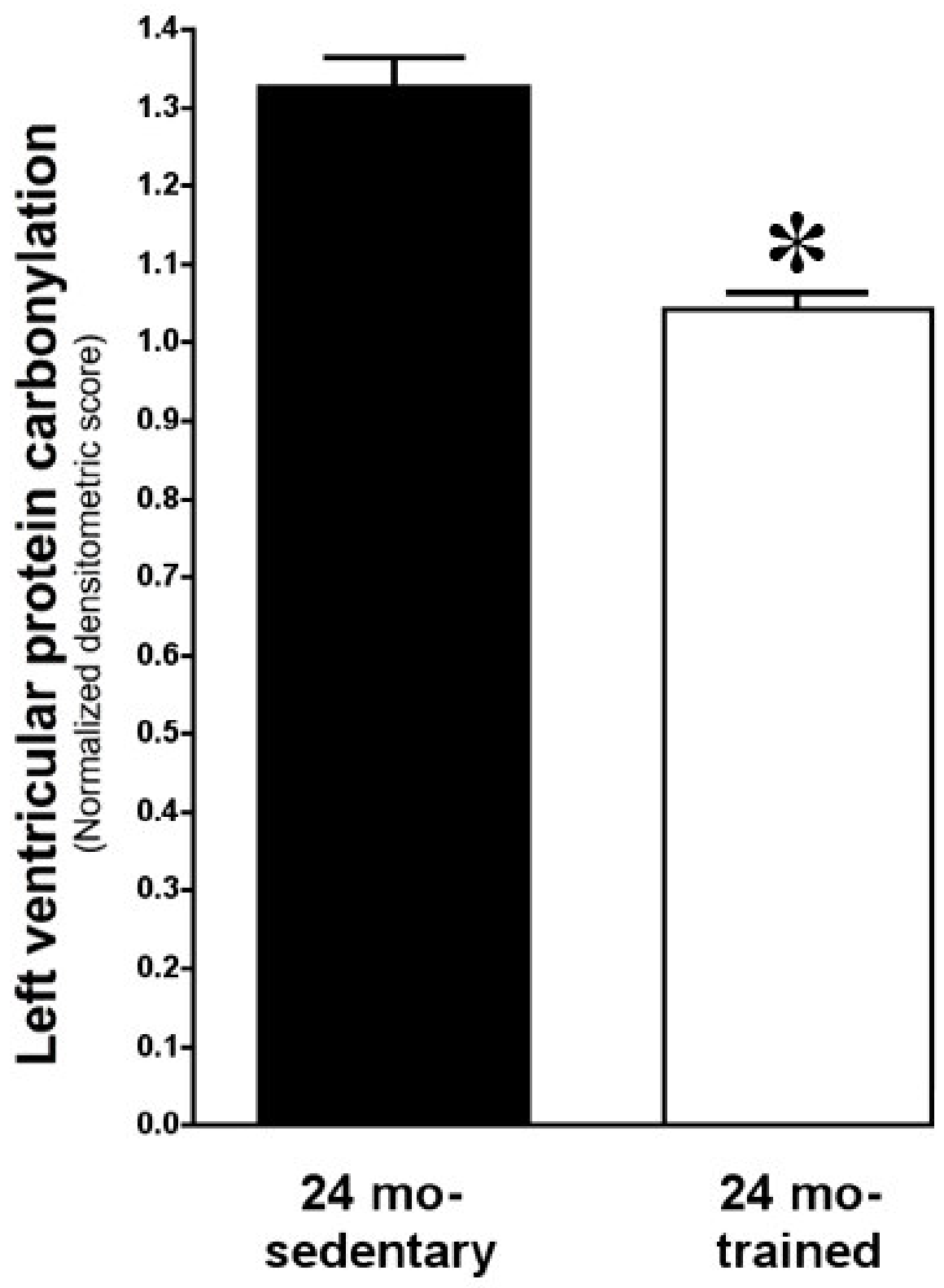


A

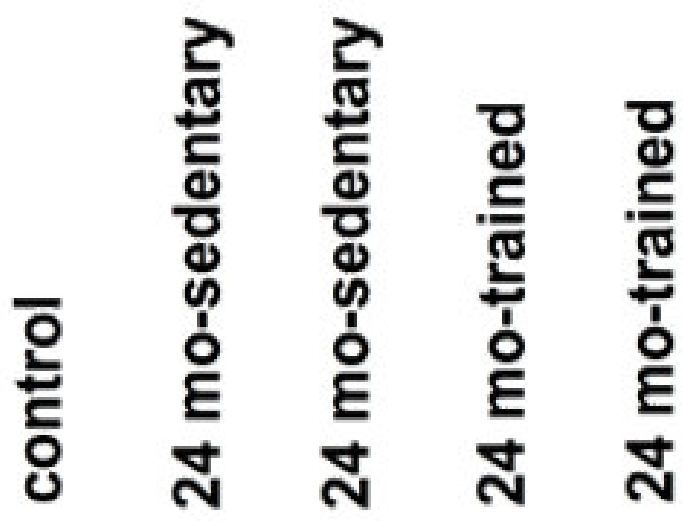

$70 \mathrm{kDa}$

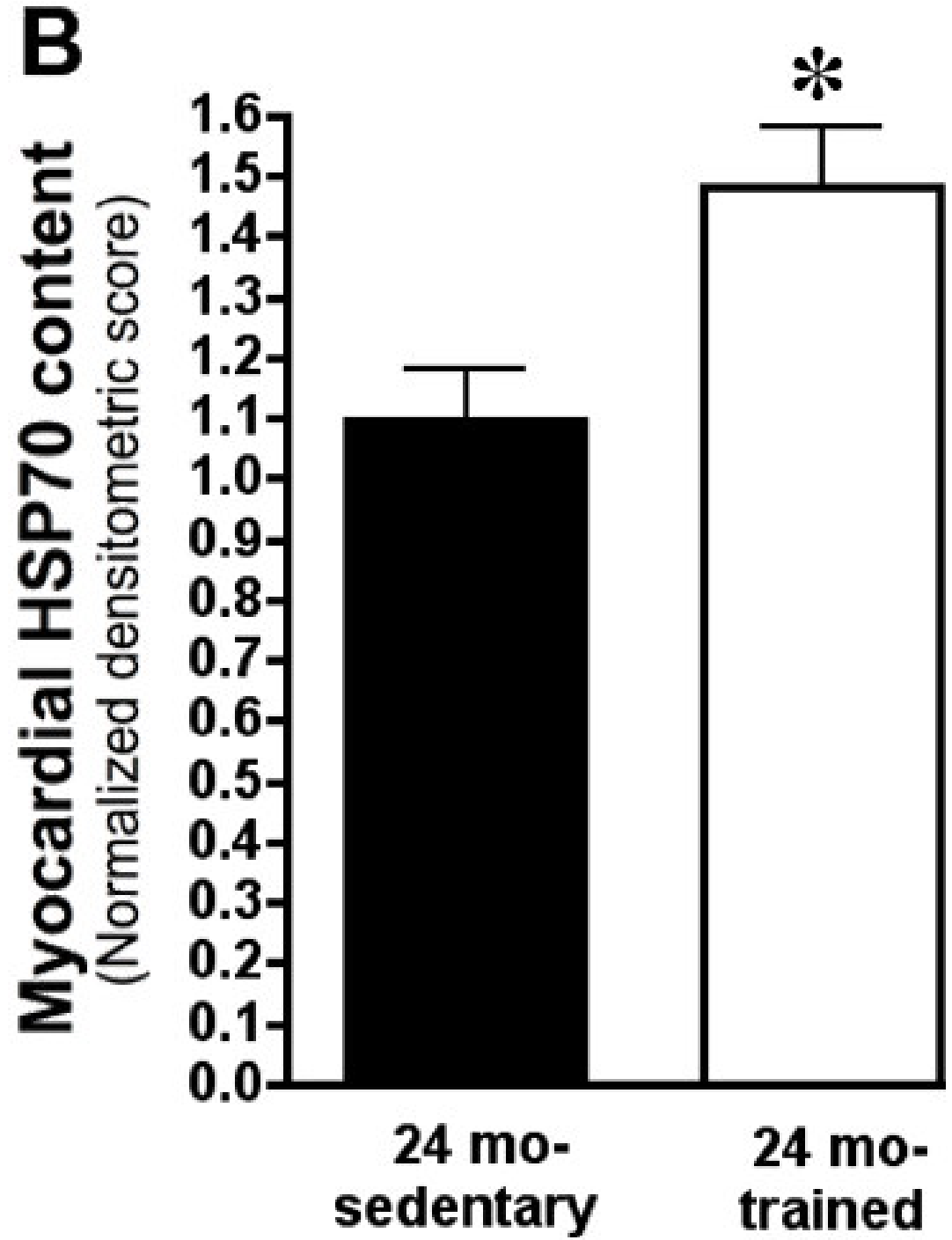


A

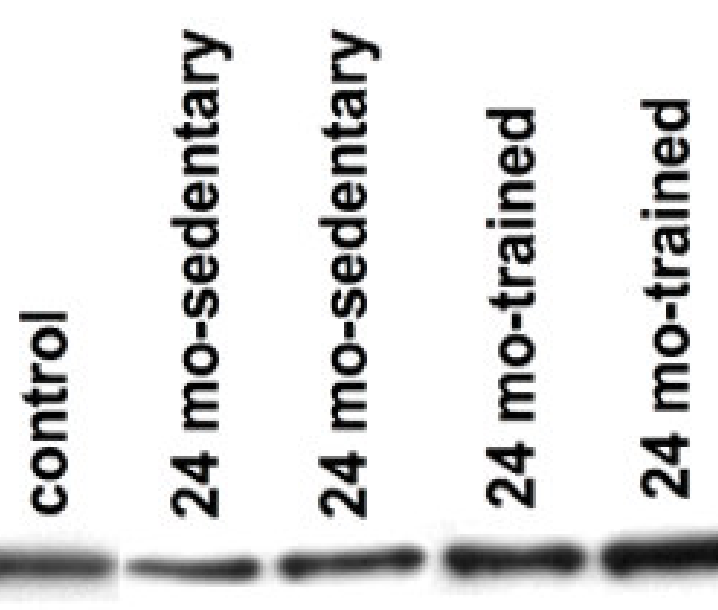

B

$140 \mathrm{kDa}$

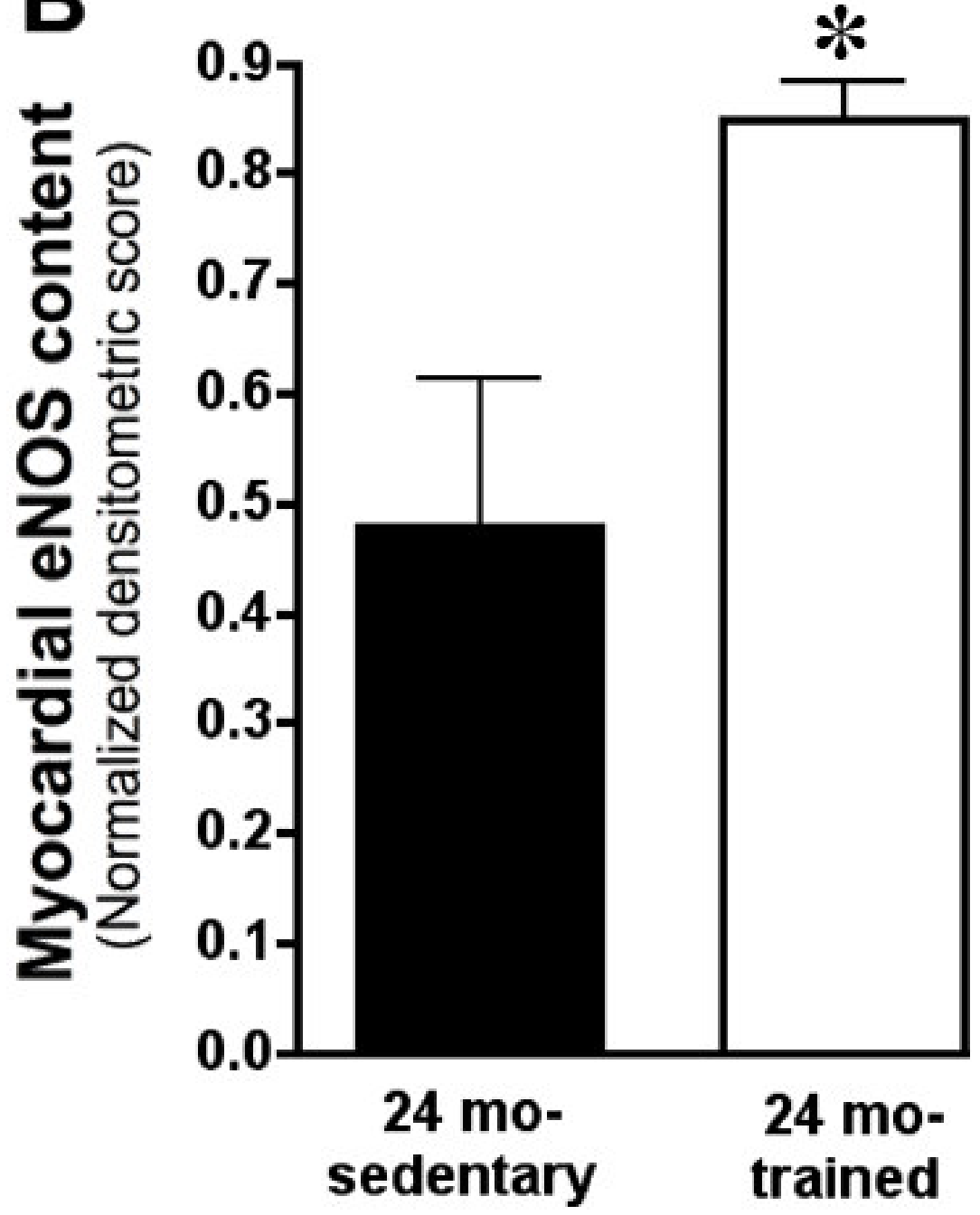

